\title{
PENGARUH PENYULUHAN UNTUK MENINGKATKAN PENGETAHUAN DAN SIKAP KELUARGA TENTANG STRATEGI PELAKSANAAN HALUSINASI DI PUSKESMAS MANGASA
}

\author{
Effect Release to Improve Family Knowledge and Attitude About Halusination Implementation Strategies \\ in Mangasa Health Center \\ Rahman $^{1}$ \\ Sri Wahyuni Awaluddin² \\ Jurusan Keperawatan Politeknik Kesehatan Kemenkes Makassar \\ Corresponding author: rahman.nasar63@gmail.com
}

\begin{abstract}
Family is the main support system in the care of mental illness patients in preventing recurrence and accelerating rehabilitation in order to be productive in teh community. Therefore an action strategy is needed for the family in carrying out home care. Strategy for Implementing Nursing Intervention is a tool that is used as a guide by a soul nurse when interacting with clients. This study aimed to determine the influence of health education in improving family knowledge, attitudes and skills about strategies for implementing care for mental illness patients. This study was conducted in quasy experiments with the design of pretets-posttest. random subject control The study was conducted in the work area of Mangasa Comunity Health Centre Makassar. The sample in this study was taken in total, namely 30 heads of families who had family members experiencing hallucinations. The results of this study indicate a difference in the level of knowledge and attitudes of respondents after counseling. The average knowledge score after intervention was 33.53 (95\% Cl; 32.94 -34.12) and attitudes 13.06 (95\% Cl; 10.51 - 11.75). Researchers suggest the need for continuous counseling to improve family knowledge and attitudes regarding the care of hallucinatory patients, the need to establish collaboration in the community groups to create support systems for mental patients, and the need to establish mental health awareness groups as a place to serve and train families of mental illness patients.
\end{abstract}

Key words: Health education, Knowledge, Attitudes, Family

\begin{abstract}
ABSTRAK
Keluarga merupakan sistem pendukung utama dalam perawatan pasien jiwa dalam mencegah kekambuhan dan mempercepat rehabilitasi agar dapat kembali produktif. Oleh karenanya dibutuhkan kemampuan strategi tindakan dalam melakukan perawatan di rumah. Strategi Pelaksanaan Tindakan Keperawatan merupakan alat yang dijadikan sebagai panduan oleh seorang perawat jiwa ketika berinteraksi dengan klien. Tujuan penelitian ini adalah diketahuinya pengaruh penyuluhan dalam meningkatkan pengetahuan, sikap dan keterampilan keluarga tentang strategi pelaksanaan tindakan keperawatan jiwa. Penelitian ini dilakukan secara quasy eksperimen dengan desain pretets-postest kelompok kontrol subjek random. Penelitian dilaksanakan di wilayah kerja PKM Mangasa Makassar Sampel dalam penelitian ini diambil secara total samping, yaitu 30 kepala keluarga yang mempunyai anggota keluarga mengalami halusinasi. Hasil penelitian ini menunjukkan adanya perbedaan tingkat pengetahuan dan sikap responden setelah dilakukan penyuluhan. Rata-rata skor pengetahuan setelah intervensi 33,53 (95\% Cl; 32,94 $34,12)$ dan sikap $13,06(95 \% \mathrm{Cl} ; 10,51$ - 11,75). Peneliti menyarankan perlunya pemberian penyuluhan secara berkesinambungan demi meningkatkan pengetahuan dan sikap keluarga mengenai perawatan pasien halusinasi, perlunya melibakan kelompok masyarakat untuk menciptakan support system pada pasien gangguan jiwa, serta perlunya dibentuk kelompok masyarakat sadar kesehatan jiwa sebagai wadah untuk melayani dan melatih keluarga pasien jiwa.
\end{abstract}

\section{Kata Kunci: Penyuluhan, Pengetahuan, Sikap Keluarga}

\section{PENDAHULUAN}

Penderita gangguan mental atau psikis di kalangan masyarakat dari masa ke masa cenderung meningkat seiring meningkatnya stressor pada manusia yang hidup di jaman modern. Terlepas dari pengaruh budaya dan kondisi lingkungan, menurut 
data yang bersumber dari kesehatan modern terutama pada masalah kesehatan jiwa, diperkirakan satu dari empat orang Indonesia menderita gangguan jiwa Azwar, (2005).

Gangguan jiwa berat (psikosis) salah satunya adalah skizoprenia. Dari seluruh klien skizofrenia, 70\% diantaranya mengalami halusinasi. Halusinasi merupakan gangguan persepsi dimana klien mempersepsikan sesuatu yang sebenamya tidak terjadi Maramis, (2004). Menurut Stuart \& Sundeen (1995), 70\% halusinasi adalah halusinasi auditorik, $20 \%$ halusinasi visual, $10 \%$ halusinasi pengecapan dan penciuman. Halusinasi yang tidak mendapatkan pengobatan maupun perawatan, lebih lanjut dapat menyebabkan perubahan perilaku seperti agresi, bunuh diri, menarik diri dari lingkungan dan dapat membahayakan diri sendiri, orang lain dan lingkungan Stuart \& Laraia, (1995).

Gangguan jiwa berat (Skizofrenia) 14.921 orang (0,26 permil). Ini di bawah prevalensi gangguan jiwa berat nasional yang mencapai 1,7 per mil. Gangguan mental emosional seperti depresi dan kecemasan mencapai $533.721(9,3 \%)$.

Keluarga merupakan sistem pendukung utama yang memberi perawatan langsung pada setiap keadaan sehat dan sakit pasien. Keluarga mempunyai kemampuan untuk mengatasi masalah akan dapat menekan perilaku maladaptive (pencegahan sekunder) dan memulihkan perilku adaptif (pencegahan tertier) sehingga derajat kesehatan pasien dan keluarga dapat ditingkatkan secara optimal Keliat, (2008).

\section{METODE}

Penelitian ini dilakukan secara quasy eksperimen dengan desain pretets-postest kelompok kontrol subjek random. Penelitian ini terbagi atas 3 tahap: 1. Tahap perencanaan (assessmen kebutuhan di lapangan, persiapan intsrumen, materi dan modul); 2. Pelaksanaan ( pre test, penyuluhan selama 5 kali, post test); 3. Diseminasi hasil. Lokasi penelitian di wilayah kerja PKM Mangasa Makassar. Sampel dalam penelitian ini diambil secara total samping, yaitu 30 kepala keluarga yang mempunyai anggota keluarga mengalami halusinasi

\section{HASIL}

Tabel 1 Karakteristik Kepala Kelurga berdasarkan Pendidikan dan Jenis Pekerjaan $(n=30)$ di Wilayah Puskesmas Mangasa Kota Makassar

\begin{tabular}{|c|c|c|c|c|c|}
\hline \multirow[t]{2}{*}{ Variabel } & & $\begin{array}{l}\text { lm } \\
k \\
\text { ensi } \\
\text { 15) }\end{array}$ & & $\begin{array}{l}\text { npo } \\
\text { itrol } \\
15)\end{array}$ & $\begin{array}{c}\text { Total } \\
(n=30)\end{array}$ \\
\hline & $\mathrm{n}$ & $\%$ & $n$ & $\%$ & $\%$ \\
\hline
\end{tabular}

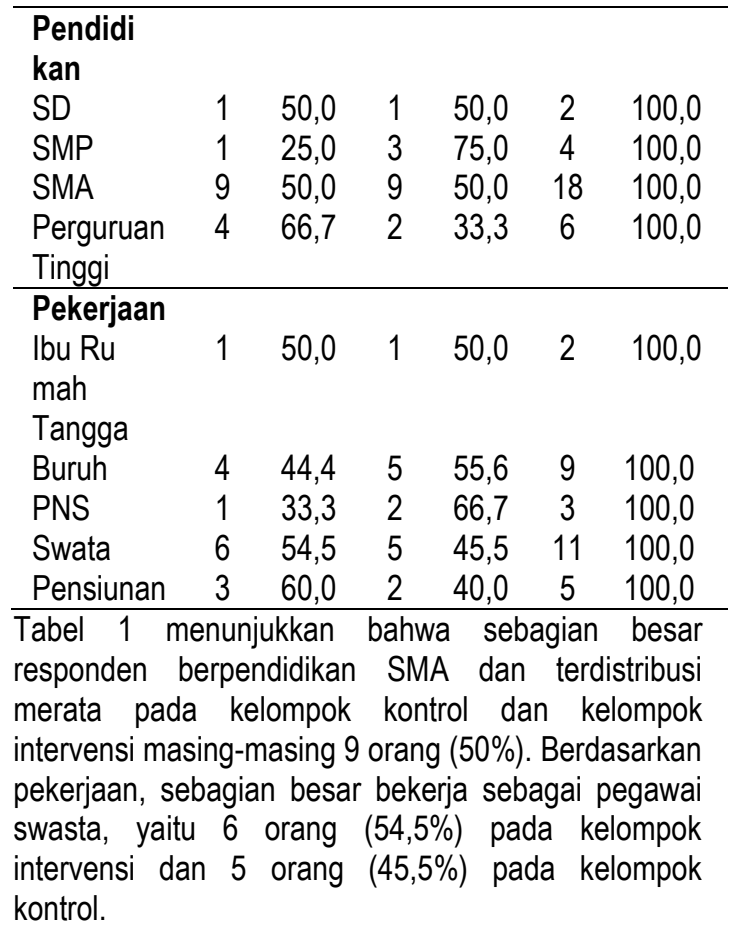

Tabel 2. Distribusi Pengetahuan Responden tentang Strategi Pelaksanaan Tindakan Keperawatan Halusinasi $(n=30)$ di Wilayah Puskesmas Mangasa Kota Makassar

\begin{tabular}{|c|c|c|c|}
\hline $\begin{array}{l}\text { Penge } \\
\text { tahuan }\end{array}$ & $\begin{array}{c}\text { Kelompok } \\
\text { Intervensi } \\
(n=15)\end{array}$ & $\begin{array}{c}\text { Kelompok } \\
\text { Kontrol } \\
(n=15)\end{array}$ & Total $(n=30)$ \\
\hline \multicolumn{4}{|c|}{ Sebelum Intervensi } \\
\hline $\begin{array}{l}\text { Mean } \\
\text { (SD) }\end{array}$ & $31,93(2,40)$ & $29,40(1,84)$ & $30,66(2,46)$ \\
\hline Median & 32,00 & 29,00 & 30,00 \\
\hline $\begin{array}{l}\text { Min - } \\
\text { Max }\end{array}$ & $28,00-36,00$ & $26,00-33,00$ & $26,00-36,00$ \\
\hline $95 \% \mathrm{Cl}$ & $30,60-33,26$ & $28,37-30,42$ & $29,74-31,58$ \\
\hline \multicolumn{4}{|c|}{ Setelah Intervensi } \\
\hline $\begin{array}{l}\text { Mean } \\
\text { (SD) }\end{array}$ & $33,53(1,06)$ & $31,46(3,06)$ & $32,50(2,48)$ \\
\hline Median & 34,00 & 31,00 & 33,00 \\
\hline $\begin{array}{l}\text { Min - } \\
\text { Max }\end{array}$ & $32,00-35,00$ & $26,00-35,00$ & $26,00-35,00$ \\
\hline $95 \% \mathrm{Cl}$ & $32,94-34,12$ & $29,76-33,16$ & $31,57-33,42$ \\
\hline
\end{tabular}

Tabel 2 menunjukkan bahwa rata-rata skor pengetahuan kelompok intervensi sebelum dilakukan penyuluhan adalah 31,93 (Cl 95\%: 30,60-33,26). Hasil estimasi interval dapat disimpulkan bahwa $95 \%$ diyakini skor pengetahuan kelompok intervensi sebelum penyuluhan diantara 30,60-33,26. 
$\begin{array}{lllll}\text { pok } & 5 & 6 & 6 & 9\end{array}$

Kontrol

*independen sample $t$ test dengan $\alpha<0,05$

Tabel 5. menunjukkan rata-rata skor pengetahuan setelah penyuluhan pada kelompok intervensi adalah 33,53 dengan standar deviasi 0,40. Sedangkan pada kelompok kontrol 31,46 dengan standar deviasi 3,06. Hasil uji statistik didapatkan nilai $p=0,024$ maka dapat disimpulkan bahwa ada perbedaan skor pengetahuan antara kelompok kontrol dan intervensi setelah penyuluhan.

Tabel 6. Perbandingan Skor Sikap Sebelum Penyuluhan antara Kelompok Kontrol dan Intervensi $(n=30)$

\begin{tabular}{|c|c|c|c|c|c|c|}
\hline Sikap & $n$ & $\begin{array}{l}\mathrm{Me} \\
\text { an }\end{array}$ & SD & $\begin{array}{c}\text { Min- } \\
\text { Mak } \\
\text { S }\end{array}$ & Z & $p$ \\
\hline $\begin{array}{l}\text { Kelom } \\
\text { pok } \\
\text { Inter }\end{array}$ & 15 & $\begin{array}{c}12,4 \\
6\end{array}$ & $\begin{array}{c}1,7 \\
6\end{array}$ & $\begin{array}{c}10- \\
14\end{array}$ & & \\
\hline $\begin{array}{l}\text { vensi } \\
\text { Kelom } \\
\text { pok } \\
\text { Kon } \\
\text { trol }\end{array}$ & 15 & 9,86 & $\begin{array}{c}1,0 \\
6\end{array}$ & $8-11$ & $\begin{array}{c}3,4 \\
5\end{array}$ & $\begin{array}{c}0,00 \\
0^{*}\end{array}$ \\
\hline
\end{tabular}

Tabel 6. menunjukkan rata-rata skor sikap pada kelompok intervensi sebelum penyuluhan adalah 12,46 dengan standar deviasi 1,76. Skor terendah 10 dan tertinggi 14. Sedangkan pada kelompok kontrol, rata-rata skor sikap sebelum penyuluhan 9,86 dengan standar deviasi 1,06. Skor terendah 8 dan tertinggi 11 . Hasil uji statistik didapatkan nilai 0,000 maka dapat disimpulkan ada perbedaan skor sikap antara kelompok intervensi dan kelompok kontrol sebelum penyuluhan.

Tabel 7. Perbandingan Skor Sikap Setelah Penyuluhan antara Kelompok Kontrol dan Intervensi $(n=30)$ di Wilayah Puskesmas Mangasa Kota Makassar

\begin{tabular}{|c|c|c|c|c|c|c|}
\hline Sikap & $n$ & $\begin{array}{c}\text { Mea } \\
n\end{array}$ & SD & $\begin{array}{c}\text { Min- } \\
\text { Mak } \\
\text { S }\end{array}$ & $z$ & $p$ \\
\hline Kelom & 1 & 13,0 & 0,2 & 13- & & \\
\hline $\begin{array}{l}\text { pok } \\
\text { Inter }\end{array}$ & 5 & 6 & 5 & 14 & & \\
\hline vensi & & & & & 4,5 & 0,000 \\
\hline Kelom & 1 & 11,1 & 1,1 & $9-13$ & 0 & * \\
\hline $\begin{array}{l}\text { pok } \\
\text { Kon } \\
\text { trol }\end{array}$ & 5 & 3 & 2 & & & \\
\hline
\end{tabular}

${ }^{\star}$ Mann Whitney dengan $\mathrm{a}<0,05$
Tabel 7 .menunjukkan rata-rata skor sikap pada kelompok intervensi setelah penyuluhan adalah 13,06 dengan standar deviasi 0,25. Skor terendah 13 dan tertinggi 14. Sedangkan pada kelompok kontrol, ratarata skor sikap setelah penyuluhan 11,13 dengan standar deviasi 1,12. Skor terendah 9 dan tertinggi 13. Hasil uji statistik didapatkan nilai 0,000 maka dapat disimpulkan ada perbedaan skor sikap antara kelompok intervensi dan kelompok kontrol setelah penyuluhan.

\section{PEMBAHASAN}

Pada penelitian ini diketahui bahwa tingkat pengetahuan antara kelompok kontrol dan kelompok intervensi tidak terlalu jauh berbeda. Kedua kelompok ini memiliki latar belakang yang sama yaitu sebagian besar berpendidikan SMA sehingga dapat ditarik kesimpulan bahwa kemampuan untuk menerima informasi pada setiap responden rata-rata sSetelah intervensi dapat dilihat bahwa rata-rata skor pada kelompok intervensi menunjukkan peningkatan.

Hasil penelitian ini menunjukkan bahwa penyuluhan mampu meningkatkan pengetahuan keluarga mengenai strategi pelaksanaan tindakan keperawatan pada pasien anak/remaja yang mengalami halusinasi.Seperti diketahui, gangguan jiwa tidak hanya menimbulkan penderitaan bagi individu penderitanya tetapi juga bagi orang yang terdekatnya. Biasanya keluargalah yang paling terkena dampak bagi hadirnya gangguan jiwa di keluarga mereka. Selain biaya perawatan tinggi pasien juga membutuhkan perhatian dan dukungan yang lebih dari masyarakat terutama keluarga, sedangkan pengobatan gangguan jiwa membutuhkan waktu yang relatif lama, bila pasien tidak melanjutkan pengobatan maka akan mengalami kekambuhan (Arif, 2006). Beberapa faktor yang dapat mempengaruhi pasien gangguan jiwa mengalami kekambuhan antara lain yaitu, pengetahuan, pendidikan, informasi, sosial ekonomi, dan peran keluarga.

Berdasarkan penelitian di Inggris (Vaugh, 1976) dan di AS (Synder, 1981) memperlihatkan bahwa keluarga dengan ekspresi emosi yang tinggi dengan klien, diperkirakan klien akan kambuh dalam waktu 9 bulan, hasilnya $57 \%$ kembali dirawat dari keluarga dengan ekspresi emosi tinggi dan $17 \%$ kembali dirawat dari keluarga dengan ekspresi emosi keluarga yang rendah. Setelah klien pulang ke rumah, sebaiknya klien melakukan perawatan lanjutan pada pukesmas di wilayahnya yang mempunyai program kesehatan jiwa, dan peran keluarga sangat dibutuhkan dalam proses penyembuhan klien di rumah (Yosep, 2009).

Selain informasi, pengalaman dalam menangani anggota keluarga yang mengalami gangguan jiwa juga mempengaruhi tingkat 
pengetahuan. Suliha (2002) mengemukakan bahwa salah satu faktor yang mempengaruhi pengetahuan adalah pengalaman. Pengalaman yang dialami oleh responden tentang orang gangguan jiwa di sekitar responden menjadi sumber informasi terhadap pengetahuan responden tentang pencegahan kekambuhan gangguan jiwa.

Beberapa penelitian telah menunjukkan bukti keberhasilan penyuluhan dalam meningkatkan pengetahuan keluarga mengenai penanganan pasien gangguan jiwa. Suhita dan Fazrin (2014) melakukan penelitian dengan pre experimental design pada 12 orang yang memiliki anggota keluarga penderita schizophrenia di kota Kediri. Hasil penelitiannya menunjukkan peningkatan pengetahuan mengenai strategi pelaksanaan tindakan halusinasi setelah pemberian intervensi pendidikan kesehatan.

Perbedaan sikap kelompok perlakuan dengan kelompok kontrol tentang SPTK halusinasi sebelum dan setelah penyuluhan Pada penelitian ini menunjukkan bahwa rata-rata skor sikap pada kelompok kontrol dan kelompok intervensi tidak terlalu jauh berbeda sebelum dilakukannya penyuluhan. Setelah dilakukan penyuluhan, rata-rata skor sikap pada kelompok intervensi lebih tinggi dari pada kelompok kontrol. Hal ini menunjukkan adanya perbedaan sikap yang signifikan pada kelompok intervensi setelah dilakukannya penyuluhan.

Adanya perubahan skor sikap menunjukkan pentingnya pemberian penyuluhan secara terus menerus kepada keluarga pasien secara khusus dan pada masyarakat secara umum. Selama ini, sikap keluarga cenderung memperlakukan pasien gangguan kejiwaan dengan disembunyikan, diisolasi, dikucilkan bahkan sampai ada yang dipasung. Di negara maju seperti Inggris, stigma yang akirnya mempengaruhi sikap masyarakat mengenai pasien gangguan jiwa masih belum menunjukkan perbaikan selama kurun waktu 2009-2012 (Evans-Lacko, Henderson dan Thornicroft, 2013). Di Indonesia sendiri, stigma masyarakat mengenai pasien gnagguan jiwa juga belum mengalami perbaikan yang berarti. Hal ini menjadi suatu permasalahan yang penting untuk dicari solusinya, karena keluarga merupakan sumber pengobatan yang paling berperan bagi anggota keluarganya yang sakit. Sikap yang baik oleh keluarga serta dukungan sosial dapat melemahkan dampak stress dan secara langsung memperkokoh kesehatan mental individu.
Beberapa penelitian sebelumnya telah menunjukkan keberhasilan pemberian penyuluhan dalam meningkatkan sikap positif pada keluarga pasien gangguan jiwa. Livyanovitasari, Noorhamdani, Astari (2017) mengungkapkan adanya perbedaan signifikan terhadap sikap dan mekanisme koping keluarga penderita gangguan jiwa setelah dilakukannya terapi supportif kelompok, dimana salah satu kegiatannya adalah penyuluhan. Suhita dan Fazrin (2014) melakukan penelitian dengan pre experimental design pada 12 orang yang memiliki anggota keluarga penderita schizophrenia di kota Kediri. Hasil penelitiannya menunjukkan peningkatan skor pengetahuan mengenai strategi pelaksanaan tindakan halusinasi setelah pemberian intervensi pendidikan kesehatan.

Keluarga merupakan faktor yang sangat penting dalam proses kesembuhan klien yang mengalami gangguan jiwa. Sikap keluarga bermanfaat untuk perkembangan menuju kepribadian yang sehat tanpa gangguan. Apabila sikap semacam ini tidak ada, maka keberhasilan penyembuhan sangat berkurang atau bahkan tidak akan menemui hasil.

\section{KESIMPULAN}

1. Terdapat perbedaan tingkat pengetahuan pada kelompok intervensi setelah dilakukan penyuluhan

2. Terdapat perbedaan sikap pada kelompok intervensi setelah dilakukan penyuluhan

\section{SARAN}

1. Pelaksanaan penyuluhan kesehatan sebaiknya dilakukan secara terus menerus dan berkesinambungan demi meningkatkan pengetahuan dan sikap positif keluarga dalam merawat pasien gangguan jiwa utamanya pada usia anak dan remaja

2. Penyuluhan kesehatan perlu melibatkan unsur masyarakat, bukan hanya terfokus pada keluarga pasien gangguan jiwa, agar pemahaman dan dukungan masyarakat dapat tercipta untuk membantu kesembuhan pasien gangguan jiwa

3. Perlunya diciptakan kelompok masyarakat sadar kesehatan jiwa, melalui program pelatihan kesehatan jiwa untuk menghasilkan kader yang dapat membantu memberikan pengetahuan dan melatih keluarga pasien gangguan jiwa.

\section{DAFTAR PUSTAKA}

Azwar. (2005). Sikap Manusia: Teori dan Pengukurannya (2 ed.). Yokyakarta: Pustaka Pelajar. Arif (2006). Skizophrenia:Memahami Dinamika Keluarga Pasien. Bandung: Rafika Aditama Depkes. (1995). Survey Kesehatan Mental Rumah Tangga. Jakarta: Depkes R.I. 
Depkes (1997). Petunjuk Pelaksanaan Dan Deteksi Dini Tumbuh Kembang Balita Bagi Petugas Puskesmas. Jakarta: Depkes Rl.

Evans-Lacko, Henderson, Thornocroft. (2013). Public Knowledge, Attitudes adn Behavior Regarding Mental Illness in England 2009-2012. The British Jurnal of Psychiatry. Vol.22 e55,pp s51-57.

Fhitrishia, F. (2008). Peranan Keluarga dalam Proses Pengobatan Pasien Gangguan Jiwa. e-Skripsi Universitas Andalas. Retrieved 25 April 2018, 2018, from http://scholar.unand.ac.id/id/eprint/1748

Fitria, N. (2012). Prinsip Dasar dan Aplikasi Penulisan Laporan Pendahuluan dan Strategi Pelaksanaan Tindakan Keperawatan (Revisi ed.). Jakarta: Salemba Medika.

Fontaine, \& Cook. (2003). Mental Health Nursing. New Jersey: Prentice Hall.

Friedman, Marilin, M., Bowden, Vicky.R., Jones, \& G., E. (2010). Buku Ajar Keperawatan Keluarga Riset, Teori dan Praktek. Jakarta: EGC.

Hawari (2003). Pendekatan Holistik Pada Gangguan Jiwa Schizophrenia. Jakarta: Balai Penerbit FKUI.

Keliat, B. A. (2008). Peran Serta Keluarga dalam Perawatan Klien Gangguan Jiwa. Jakarta: EGC.

Keliat, B. A., Panjaitan, R. U., \& Helena, N. (2006). Proses Keperawatan Kesehatan Jiwa. Jakarta: Buku Kedokteran: EGC.

Kusumaningtyas (2017) Pengaruh Pendidikan Kesehatan Jiwa Keluarga Terhadap Pengetahuan dan Sikap Pencegahan Kekambuhan Gangguan Jiwa Di Desa Makam Haji Kecamatan Kartasura Kabupaten Sukoharjo. Thesis. Universitas Muhammadiyah Surakarta.

Livyanovitasari, Noorhamdan, Astari. (2017). The Effect Of Supportif Group Therapy on the Burden and Coping Mechanisms in Caring for Family Members Who Suffer Schizophrenia. Nurseline Journal.Vol 2 No.2 November 2017.

Notoatmodjo, S. (2012). Pengantar Pendidikan Kesehatan dan IImu Perilaku. Yogyakarta: Andi Offset.

Maramis, W.F. (2004). Catatan IImu Kedokteran Jiwa. Airlangga Press: Surabaya

Notoatmodjo, S. (2003). IImu Kesehatan Masyarakat. Jakarta: Rineka Cipta.

Stuart, \& Laraia. (1995). Buku Saku Keperawatan Jiwa (3 ed.). Jakarta: EGC.

Stuart, G. W., \& Sundeen, S. J. (1995). Principle and Practice of Psychiatric Nursing. St. Louis, Missiouri: Mosby Year Book.

Sudiharto (2007). Asuhan Keperawatan Keluarga Dengan Pendekatan Transkultural. Jakarta:EGC

Sugiyono. (2009). Metode Penelitian Pendidikan. Jakarta: Alfabeta.

Suhita,. Fazrin. (2014). Pengaruh Health Education Tentang Strategi Pelaksanaan Halusinasi Pada Keluarga Terhadap Peran Keluarga DAlam Membantu Klien Schizophrenia Mengontrol Halusinasi Di Kota Kediri. STRADA Jurnal Imiah Kesehatan.2(1).7-13.

Sulia (2002) Pendidikan Kesehatan Dalam Keperawatan. Jakarta:EGC

Supratjitno. (2004). Asuhan Keperawatan Keluarga : Aplikasi dalam Keperawatan. Jakarta: EGC.

Utami., Marlyn. (2004). Gender dan Keluarga. Jakarta: EGC 